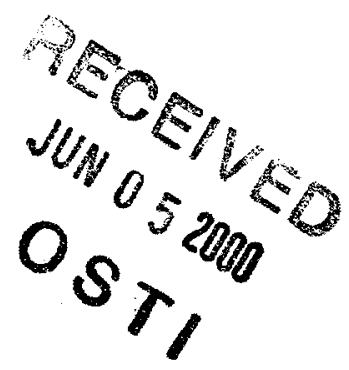

INVESTIGATION OF GROUNDWATER FLOW PATHS THROUGH COMBINED INVERSION OF STRONTIUM ISOTOPE RATIOS AND HYDRAULIC HEAD DATA

Final Report

For Period April 1, 1997 - October 31, 1999

Thomas M. Johnson

University of Illinois at Urbana-Champaign

Urbana, IL 61801

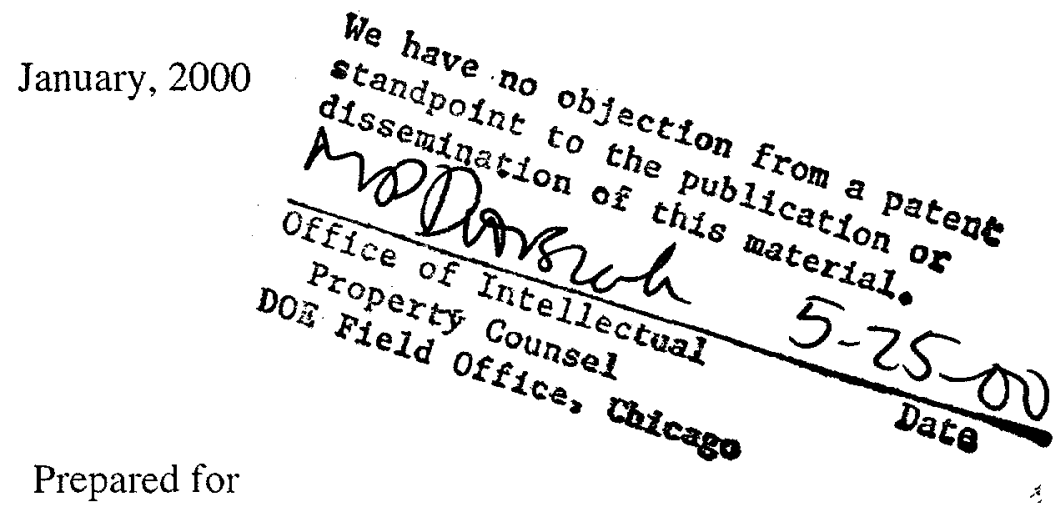

U.S. Department of Energy

Award No. DE-FG02-97ER 14759 


\section{DISCLAIMER}

This report was prepared as an account of work sponsored by an agency of the United States Government. Neither the United States Government nor any agency thereof, nor any of their employees, make any warranty, express or implied, or assumes any legal liability or responsibility for the accuracy, completeness, or usefulness of any information, apparatus, product, or process disclosed, or represents that its use would not infringe privately owned rights. Reference herein to any specific commercial product, process, or service by trade name, trademark, manufacturer, or otherwise does not necessarily constitute or imply its endorsement, recommendation, or favoring by the United States Government or any agency thereof. The views and opinions of authors expressed herein do not necessarily state or reflect those of the United States Government or any agency thereof. 


\section{DISCLAIMER}

Portions of this document may be illegible in electronic image products. Images are produced from the best available original document. 


\section{Summary}

Strontium ( $\mathrm{Sr}$ ) stable isotope ratios were used as a natural groundwater flow tracer in and near the Idaho National Engineering and Environmental Laboratory (INEEL). Important fast and slow-flow zones were identified using this technique. This was a new application of $\mathrm{Sr}$ isotopes and, reinforced by uranium (U) isotope data collected by Los Alamos researchers, it demonstrated that radiogenic isotope ratios have unique properties as groundwater tracers that make them highly useful in certain groundwater systems. The journal articles resulting from this project will encourage greater use of this new tool in groundwater studies, and the basic results will help INEEL scientists better understand their aquifer.

The results were interpreted quantitatively through construction of numerical models that capture the many details of this hydrologic system and simultaneously consider hydraulic head and isotope ratio data. The modeling results reinforce the qualitative interpretation of the data and constrain the relative velocities of the fast and slow flow zones. The aims of the project deviated little from the initial plan. More effort was expended in qualitative data analysis and gathering of aquifer information than planned, but the overall goals of the project were attained.

\section{Results}

The first set of results consisted of $\mathrm{Sr}$ stable isotope ratio $\left({ }^{87} \mathrm{Sr} /{ }^{86} \mathrm{Sr}\right)$ and dissolved element concentration data on a suite of approximately 90 groundwater samples from in and near the Idaho National Engineering and Environmental Laboratory (INEEL). Subsamples of many of these were provided to researchers at Los Alamos National Laboratory (LANL), who measured ${ }^{234} \mathrm{U} /{ }^{238} \mathrm{U}$ ratios as part of an EMSP program project. These data were assembled into contour plots via Kriging software. The clear patterns in the ${ }^{87} \mathrm{Sr} /{ }^{86} \mathrm{Sr}$ and ${ }^{234} \mathrm{U} /{ }^{238} \mathrm{U}$ strongly suggest relatively fast groundwater flow in an elongate zone passing through the center of the southern INEEL boundary, and slower flow on both sides of this zone (see figures in attached manuscript). Calculations suggest the contrast in groundwater velocity between the fast and slow flow zones is about a factor of five.

Concentrations of 14 dissolved elements in the groundwater samples were obtained by Inductively Coupled Plasma- Mass Spectrometry (ICP-MS) through continued collaboration with Dr. Thomas Bullen of the U.S. Geological Survey in Menlo Park. These data provided additional information on regional flow patterns and helped to highlight the unique properties of the isotope ratios as groundwater tracers.

The implications of these results are twofold. First, the mapping of important slow and fast flow zones gives environmental management scientists better information about potential regional contaminant migration patterns. Second, there are broader implications for the strengths of these isotope ratios as naturally occurring groundwater tracers. Compared to the elemental concentrations, the isotope ratios are easier to interpret in groundwater systems like this one 
because their response to chemical reaction between water and rock is simpler. Thus, the fact that two isotope ratios give similar patterns, but the concentration data give less clear, inconsistent patterns is expected and suggests that these isotope ratios may be uniquely useful in many groundwater studies. These conclusions are the focus of a journal article submitted to Geology (attached).

The second focus of the project used computer models to analyze the ${ }^{87} \mathrm{Sr} /{ }^{86} \mathrm{Sr}$ and hydraulic head data quantitatively. The post-doctoral researcher on the project, Dipak Sahoo, used SUTRA, an established groundwater flow/solute transport/reaction code to create a twodimensional groundwater flow and water-rock interaction model for the INEEL area. Chris Doughty, the Berkeley Lab collaborator, performed a series of simulations with MODFLOW, the pseudo-3 dimensional software previously used by the USGS to model this aquifer, and determined that a 2-dimensional model considering only the top layer of the aquifer was a sufficiently close approximation, given the area considered and the objectives of this project. Hydraulic head data were compiled from previous USGS and INEEL reports and data files, and the ${ }^{87} \mathrm{Sr} /{ }^{86} \mathrm{Sr}$ boundary conditions of the model were specified. The model domain was broken into several areas or zones and a forward model that calculated the hydraulic head and ${ }^{87} \mathrm{Sr} /{ }^{86} \mathrm{Sr}$ ratio as a function of position, depending on the conductivity values assigned to the zones. Finally, an optimization algorithm was developed to find the transmissivities of the zones, through progressive iteration of the forward model and adjustment of the transmissivities to better match the data.

The model confirmed the hypothesis suggested by the ${ }^{87} \mathrm{Sr} /{ }^{86} \mathrm{Sr}$ data- that the observed pattern can be produced by the existence of a relatively fast flow zone passing through the southern boundary of the INEEL flanked by slower flow zones. Furthermore, it demonstrated that the lack of a similar pattern in the head data did not obviate the fast path hypothesis. The head patterns expected near a fast flow zone are more complicated and not as readily apparent as the ${ }^{87} \mathrm{Sr}{ }^{86} \mathrm{Sr}$ patterns.

The drawback of this model is that the user must specify the shapes of the zones, and thus, it is possible to argue that the model does not consider all possible zone shapes and is therefore non-unique as a solution to the problem. To attack this weakness, the Iterated Function Systems (IFS) method was employed as an alternative to specifying zone shapes. The IFS method uses fractal representations to represent the transmissivity field with a manageable number of parameters. As with the zone-based model, an optimization routine was constructed to find values for the parameters that gave optimal fit to the head and ${ }^{87} \mathrm{Sr} /{ }^{86} \mathrm{Sr}$ data. The IFS model, with no direct user bias (e.g., specification of zones), generally identified a hightransmissivity feature roughly similar to the hypothesized fast flow path. The boundaries of this feature were not very well defined and varied between model runs, because of the limited number of parameters used to define them. Thus, the two modeling approaches complemented each other. The zone-based model reproduced the data effectively, and the IFS-based model 
provided confidence that the observed patterns in the data are best explained by a fast flow zone and not some completely different configuration not considered in the zone-based models.

The contributions of the modeling part of the study are in demonstrating methods for simultaneous, quantitative interpretation of head and water chemistry data and illustrating the complementary nature of the two data types. The modeling results suggest that geochemical data can be more easily interpreted as indicators of preferential flow zones than hydraulic head data. The results of the modeling work are publishable, but the post-doctoral researcher did not complete an acceptable manuscript. A revised and completed manuscript will be produced by the P.I. in the coming months.

\section{Future Work}

Prospects for application of this technique to other hydrologic systems and DOE sites were assessed, and it appears that groundwater fast paths related to karst at Oak Ridge National Laboratory could be identified. Reconnaissance ${ }^{87} \mathrm{Sr} /{ }^{86} \mathrm{Sr}$ data collected for the Bear Creek Valley area suggest that the waters entering karstic features in the massive carbonate rocks should have relatively high ${ }^{87} \mathrm{Sr} /{ }^{86} \mathrm{Sr}$ ratios. Increased residence time in the carbonate rocks should translate to lower ${ }^{87} \mathrm{Sr} /{ }^{86} \mathrm{Sr}$ ratios as $\mathrm{Sr}$ is acquired from rock dissolution. Contacts at the laboratory were made and this project should move forward soon, probably as a master's project for a UIUC graduate student.

Additional work at the INEEL is warranted, in order to apply this technique to its fullest extent in that setting. Sampling on a more detailed scale than that planned in this first study is possible, because of the large numbers of groundwater monitoring wells in some areas. Also, additional samples from remote areas outside the INEEL could be collected to improve our understanding of the regional mixing of groundwater masses. Finally, work with the hydrologic details of the aquifer (e.g., the exact role of sedimentary interbeds, the composition of thermal water inputs, changes in chemistry with depth in the aquifer) could also improve future use of these data and interpretations.

\section{Publications/ Manuscripts}

Johnson T. M., Roback R. C., McLing T. L., Bullen T. D., DePaolo D. J., Doughty C., Hunt R. J., Murrell M. T., and Smith R. W., Groundwater "Fast Paths" in the Snake River Plain Aquifer: Radiogenic Isotope Ratios as Natural Groundwater Tracers (Submitted to Geology)

Johnson T. M., Sahoo, D., Doughty C., and McLing T. L., Constraining Fast And Slow Groundwater Flow Zones Via Simultaneous Inverse Modeling of Sr Isotope Ratio and Hydraulic Head Data, (in preparation for Water Resources Research) 


\section{Presentations}

Johnson, T.M., McLing, T., Bullen, T.D., and DePaolo, D.J., 1997, Sr isotope evidence for a groundwater "fast path" in the Snake River Plain Aquifer, in Geological Society of America, 1997 annual meeting., Volume 29: Abstracts with Programs, p. 309.

McLing, T.L., Smith, R.W., and Johnson, T.M., 1997, The effect of hydrothermal water on the Snake River Plain Aquifer, in Geological Society of America, 1997 annual meeting., Volume 29: Abstracts with Programs, p. 323.

Roback, R.C., Murrell, M., Nunn, A., Johnson, T., McLing, T., Luo, S., and Ku, R., 1997, Groundwater mixing, flow-paths and water/ rock interaction at INEEL; evidence from uranium isotopes, in Anonymous, ed., Geological Society of America, 1997 annual meeting., Volume 29: Abstracts with Programs, p. 308.

Johnson T. M., Sahoo, D., McLing T. L., Doughty C., DePaolo D. J., and Smith R. W., 1998, EM/ER Project: Investigation Of Groundwater Flow Paths Through Combined Inversion Of Strontium Isotope Ratios And Hydraulic Head Data, Environmental Management Science Program Workshop, Chicago, IL, July $27^{\text {th }}$ to $30^{\text {th }}$, U.S. Dept. of Energy, pp. 417-419.

Sahoo, D., Johnson T. M., Doughty C., 1998, Utilizing Natural Sr Isotope Ratios to Determine Preferential Flow Paths in Subsurface Aquifers on a Regional Scale, EOS, Transactions AGU, Vol. 79, No. 17, p. 301. 


\title{
Groundwater "Fast Paths" in the Snake River Plain Aquifer: Radiogenic Isotope Ratios as Natural Groundwater Tracers
}

\author{
Thomas M. Johnson*, Robert C. Roback", Travis L. McLing ${ }^{\star}$, Thomas D. Bullen, Donald. J. \\ DePaolo", Christine Doughty", Randall J. Hunt ${ }^{\llbracket}$, Michael T. Murrell ${ }^{\star}$
}

*Geology Department

University of Illinois at Urbana-Champaign

245 Natural History Building, MC-102

Urbana, IL 61801, USA

${ }^{\dagger}$ Chemical Science and Technology Division Los Alamos National Laboratory

Los Alamos, NM 87545, USA.

Idaho National Environmental and Engineering Laboratory

P.O. Box 1625

Idaho Falls, ID 83415 USA.
Water Resources Division

U.S. Geological Survey

345 Middlefield Road

Menlo Park, CA 94025, USA

IWater Resources Division

U.S. Geological Survey

8505 Research Way

Middleton, WI 53562

"Earth Sciences Division

Lawrence Berkeley National Laboratory

Berkeley, CA 94720, USA. 


\section{ABSTRACT}

Groundwater ${ }^{87} \mathrm{Sr} /{ }^{86} \mathrm{Sr}$ ratios reveal the locations of fast and slow flow zones in the Snake River Plain Aquifer. Slow flow zones are marked by lower ${ }^{87} \mathrm{Sr} /{ }^{86} \mathrm{Sr}$ ratios caused by interaction with the low ${ }^{87} \mathrm{Sr}{ }^{86} \mathrm{Sr}$ host basalts, whereas a major fast flow zone appears as a high $-{ }^{87} \mathrm{Sr} /{ }^{86} \mathrm{Sr}$ area in which the water chemistry evolves much less. The locations of these fast and slow flow zones are important in prediction of solute transport in and near the Idaho National Engineering and Environmental Laboratory.

Radiogenic isotope ratios have highly useful characteristics as natural groundwater tracers, and they are especially useful in cases where waters are too old for tritium age dating and too young for radiocarbon dating. In systems with significant water-rock interaction, these isotope ratios are more easily interpreted than concentration data because they are influenced by fewer reactions and the equilibrium toward which the waters evolve is often predictable. This advantage is illustrated by the Snake River Plain ${ }^{87} \mathrm{Sr} /{ }^{86} \mathrm{Sr}$ results and ${ }^{234} \mathrm{U} /{ }^{2.38} \mathrm{U}$ data from a companion study using the same samples. 


\section{INTRODUCTION}

Groundwater flow is commonly focussed into preferential flow pathways in fractured rock aquifers (e.g., Tsang and Neretnieks, 1998). In contaminated systems, these "fast paths" must be detected and characterized for accurate risk assessment. Fast paths pose a critical problem in predicting and monitoring transport of toxic contaminants, because they can transmit contaminants rapidly to the biosphere yet may arise from subtle or hidden natural features. Detection of fast paths can be attempted through observation of anthropogenic and natural geochemical tracers. Anthropogenic tracers such as tritium (e.g., Clark and Fritz, 1997) and chlorofluorocarbons (e.g., Busenberg et al., 1993) are effective for tracking groundwater flow when residence times are less than about 50 years, but additional tools are needed for systems containing older groundwater. The natural chemistry of groundwater is rich in information, but new approaches to interpret the various solute concentration and isotopic data must be developed to fully exploit them.

${ }^{87} \mathrm{Sr} /{ }^{86} \mathrm{Sr}$ ratios in useful in groundwater studies, as they reflect the water-rock reaction histories and flow pathways of the waters. Both ${ }^{87} \mathrm{Sr}$ and ${ }^{86} \mathrm{Sr}$ are stable isotopes but, because ${ }^{87} \mathrm{Sr}$ is produced by radioactive decay of ${ }^{87} \mathrm{Rb}\left(\mathrm{t}_{1 / 2}=4.8 \times 10^{10} \mathrm{y}\right)$, the ${ }^{87} \mathrm{Sr} /{ }^{86} \mathrm{Sr}$ ratios of rocks and soils depend on their $\mathrm{Rb}$ concentrations and ages. Groundwater ${ }^{87} \mathrm{Sr} /{ }^{86} \mathrm{Sr}$ ratios are inherited from soil or rock through which the water passes, and several studies have used ${ }^{87} \mathrm{Sr} /{ }^{86} \mathrm{Sr}$ ratios as natural tracers or groundwater flow and weathering (e.g., Blum et al., 1993; Bullen et al., 1997; Johnson and DePaolo, 1997; Musgrove and Banner, 1993; Naftz et al., 1997). As water-rock interaction progresses, $\mathrm{Sr}$ isotope ratios in groundwater evolve toward the isotopic composition of $\mathrm{Sr}$ acquired from the host soil or rock. In this paper, we demonstrate the usefulness of radiogenic isotopes as indicators of preferential flow paths in systems with significant water-rock interaction, using ${ }^{87} \mathrm{Sr} /{ }^{86} \mathrm{Sr}$ data from the Snake River Plain Aquifer as an example. 


\section{HYDROGEOLOGIC SETTING AND METHODS}

The Idaho National Engineering and Environmental Laboratory (INEEL) is located above the Snake River Plain Aquifer of southern Idaho (Fig. 1). Limited, localized subsurface contamination has occurred and has motivated groundwater monitoring and protection measures (Barraclough et al., 1982; Mann and Cecil, 1990). Regional flow in the aquifer is from northeast to southwest (Fig. 1). Groundwater enters the aquifer predominantly from the Snake River to the southeast, the Yellowstone Plateau to the east, and tributary groundwater systems from Birch Creek valley, Little Lost River valley, Big Lost River valley, and other valleys to the north. Local recharge within the plain is minor compared to these inputs (Barraclough et al., 1982). Groundwater flows southwestward and discharges into the Snake River (Garabedian, 1992). An important agricultural region that utilizes the aquifer for irrigation water is located down-gradient from the INEEL. The travel time between INEEL and most of the water users is thought to be at least one hundred years (Ackerman, 1995), but the pattern of flow (i.e., locations of fast flow zones, if they exist) is not well known.

The aquifer rock is composed of layers of tongue-shaped basaltic lava flows, separated in some cases by thin sheets of interbed sediments (Barraclough et al., 1982). Water flows readily through fractures, rubble zones at the bases of the flows, and other features such as collapsed lava tubes. Groundwater flow is rapid (e.g., $300 \mathrm{~m} /$ year pore velocity) in the upper 100 to $400 \mathrm{~m}$ of the aquifer, and is slower in deeper layers (Blackwell et al., 1992; Mann and Cecil, 1986). The network of fractures through which the groundwater flows is heterogeneous on several scales: Individual lava flows have high and low permeability zones, the lavas are distributed in a nonuniform manner around each lava source, and the lava sources are grouped within the plain (Kuntz et al., 1992). Also, directional flow preferences related to the elongate shapes of the lava flows and regional lava flow directions (Welhan and Reed, 1997) likely lead to hydraulic anisotropy. In fractured, heterogeneous systems such as this it is likely that preferential flow zones in the aquifer carry most of the groundwater flow and have higher flow velocities than surrounding areas (Tsang 
and Neretnieks, 1998). Regional groundwater flow simulations have been developed (Ackerman, 1995; Garabedian, 1992). However, these studies sought to reveal broad regional flow patterns and did not concentrate on finding fast flow paths at the $50 \mathrm{~km}$ scale as we do here.

The groundwater residence times in the SRP aquifer are thought to be up to a few hundred years (Ackerman, 1995), and thus cosmogenic ${ }^{14} \mathrm{C}$ is not useful. Studies tracking contaminant plumes, chlorofluorocarbon compounds and/or "bomb pulse" radionuclides have provided information regarding groundwater flow directions and velocities (Barraclough et al., 1982; Beasley et al., 1993; Busenberg et al., 1993). However, these relatively recent anthropogenic tracers can be tracked for relatively short distances and do not reveal regional scale flow patterns. The natural groundwater chemistry reported in this study provides regional scale groundwater flow information and thus complements smaller scale studies using anthropogenic tracers.

We measured ${ }^{87} \mathrm{Sr}{ }^{86} \mathrm{Sr}$ and concentrations of 14 elements (Li, B, Na, Mg, Al, Si, K, Ca, $\mathrm{Mn}, \mathrm{Fe}, \mathrm{Rb}, \mathrm{Sr}, \mathrm{Ba}$, and $\mathrm{U}$ ) in groundwater samples collected in and near the INEEL. Fifty-five water samples were acquired via down-hole pumps after purging three well bore volumes. Samples were filtered and preserved (acidified to $\mathrm{pH}<2$ with ultra-pure $\mathrm{HNO}_{3}$ ) on site and placed into acidwashed HDPE containers. Sr was purified from the waters using a $\mathrm{Sr}$-specific ion exchange resin (Eichrom Industries). Several milliliters of water were evaporated to dryness on a hot plate, dissolved in $3 \mathrm{~N} \mathrm{HNO}_{3}$, and loaded onto $50 \mu \mathrm{l}$ volume columns of pre-washed resin. The resin was rinsed with $200 \mu l 3 \mathrm{~N} \mathrm{HNO}_{3}$, which left $\mathrm{Sr}$ on the resin and eluted all other sample components. The Sr was then eluted with $1 \mathrm{~mL}$ water. ${ }^{87} \mathrm{Sr} /{ }^{86} \mathrm{Sr}$ ratios were measured by thermal ionization mass spectrometry using a VG Sector 54 mass spectrometer and a dynamic multiple-collector technique that yielded precision of about $\pm 0.002 \%$. The long term average for the NBS-987 standard during the course of this study was $0.710284 \pm 0.000013$.

Dissolved concentrations were measured by Inductively Coupled Plasma- Mass Spectrometry (ICP-MS) using a Perkin-Elmer ELAN 6000 instrument. $\mathrm{HNO}_{3}$ was added to attain a concentration of $2 \% \mathrm{HNO}_{3}$, and a known amount of an internal standard solution containing known 
amounts of $\mathrm{Be}, \mathrm{Ge}$, and $\mathrm{Tl}$ was added. Calibration drift was monitored via frequent analysis of standard solutions, and reproducibility was confirmed by duplicate analysis of several samples at the end of the run. The duplicate results indicate that the $2 \sigma$ uncertainty of the analyses was $\pm 5 \%$ or better.

\section{RESULTS AND DISCUSSION}

Contour plots of Sr isotope ratios and selected elemental concentrations are given in Fig. 2. The pattern exhibited by the ${ }^{87} \mathrm{Sr} /{ }^{86} \mathrm{Sr}$ data is striking. Water entering the aquifer from the Birch Creek and Little Lost River valleys to the north has high ${ }^{87} \mathrm{Sr} /{ }^{86} \mathrm{Sr}(>0.71100)$ relative to waters originating east of the INEEL. The ${ }^{87} \mathrm{Sr} /{ }^{86} \mathrm{Sr}$ ratios decrease along all possible southwestward flow paths, but in some areas the ${ }^{87} \mathrm{Sr} /{ }^{86} \mathrm{Sr}$ decreases very strongly whereas in other area it decreases

less. Particularly well defined is a relatively narrow zone of high ${ }^{87} \mathrm{Sr} /{ }^{86} \mathrm{Sr}$ (the high isotope ratio zone, or HIRZ) that extends southward from the mouth of the Little Lost River valley through the southern boundary of the INEEL. A second, less pronounced high isotope ratio zone trends southeast from the mouth of Birch Creek. Zones with relatively low ${ }^{87} \mathrm{Sr} /{ }^{86} \mathrm{Sr}$ occur near the center of the INEEL (central low isotope ratio zone, CLZ) and in the western part of the INEEL (western low isotope ratio zone, WLZ). Visually, the ${ }^{87} \mathrm{Sr} /{ }^{86} \mathrm{Sr}$ patterns in figure 2 suggest a channeling of the high-ratio northern groundwater through preferential flow zones between and around the WLZ and CLZ. Below, we develop this hypothesis in light of hydrologic features the aquifer, including flow rates and directions, mixing of chemically distinct water masses and chemical interaction with the host rock.

A concurrent study has measured ${ }^{23.4} \mathrm{U} /{ }^{238} \mathrm{U}$ in most of the same groundwater samples (Roback et al., Submitted), and a strongly similar pattern exists in the data (Fig. 3). Waters entering the INEEL area from the northern tributary groundwater systems have ${ }^{234} \mathrm{U} /{ }^{2.38} \mathrm{U}$ ratios greater than $160 \mathrm{ppm}\left(1.6 \times 10^{-4}\right)$. High values persist through the HIRZ, whereas the water evolves to lower values in the CLZ and the WLZ. The close correlation of ${ }^{87} \mathrm{Sr} /{ }^{86} \mathrm{Sr}$ and ${ }^{2.34} \mathrm{U} /{ }^{2.38} \mathrm{U}$ data is 
especially significant because the systematics of $\mathrm{U}$ isotopes are different from those of $\mathrm{Sr}$ isotopes (Roback et al., Submitted). ${ }^{23.4} U\left(t_{1 / 2}=2.48 \times 10^{5} y\right)$ is part of the ${ }^{238} U\left(t_{1 / 2}=4.47 \times 10^{9}\right.$ y) radioactive decay series, and the abundance of ${ }^{234} \mathrm{U}$ in nature is controlled by concurrent production and decay. In closed systems, the ${ }^{234} U /^{238} \mathrm{U}$ ratio eventually approaches the secular equilibrium value of $5.49 \times 10^{-5}$, at which the radioactive production and decay of ${ }^{234} \mathrm{U}$ are equal. ${ }^{234} \mathrm{U} /{ }^{238} \mathrm{U}$ in rocks is generally close to this value. However, in groundwater, ${ }^{234} \mathrm{U}$ is typically enriched relative to ${ }^{2.38} \mathrm{U}$ by factors ranging from 1.5 to 10 because of preferential dissolution of ${ }^{234} \mathrm{U}$ from radiogenic crystal defects and direct ejection of ${ }^{234} \mathrm{U}$ into groundwater by alpha recoil (Osmond and Cowart, 1992). In the Snake River Plain aquifer, ${ }^{2.34} \mathrm{U} /{ }^{238} \mathrm{U}$ decreases along flow paths, presumably via dissolution of basalt with ${ }^{234} \mathrm{U} /{ }^{238} \mathrm{U}$ values close to the secular equilibrium value. Details of ${ }^{234} \mathrm{U} /{ }^{238} \mathrm{U}$ systematics in the aquifer are given in Roback et al. (submitted).

One process that is expected to control groundwater chemistry in this aquifer is regional mixing of contrasting water masses (McLing, 1994). Mixing between the northern and eastern water masses results in a northwest to southeast gradient in water chemistry. This gradient is apparent in all solute concentration and isotope ratio plots and is particularly evident in the $\mathrm{Li}$ concentration data (Fig. 2b). This mixing plays a role in defining the ${ }^{87} \mathrm{Sr} /{ }^{86} \mathrm{Sr}$ and ${ }^{234} \mathrm{U} /{ }^{238} \mathrm{U}$ patterns, but the shapes and locations of the high and low isotope ratio zones cannot be produced by this regional mixing alone.

\section{Water-Rock Interaction}

Channeling of flow through the high ratio zones, and relatively slow flow in the low ratio zones, can readily produce the observed isotope-ratio pattern. In this scenario, the high ratio zones are fast flow zones, where high ${ }^{37} \mathrm{Sr} /{ }^{86} \mathrm{Sr}$ and ${ }^{234} \mathrm{U} /{ }^{238} \mathrm{U}$ ratios in groundwater north of the INEEL persist far to the south because the water has relatively brief contact with the host rock. In the low isotope ratio zones, the same northern groundwater evolves closer to the isotopic composition of the host rock $\left({ }^{87} \mathrm{Sr} /{ }^{86} \mathrm{Sr}=0.7070 \pm 0.0003\right.$; Leeman and Manton, 1971; Reed et al., 1997; 
${ }^{2.34} \mathrm{U} /{ }^{2.38} \mathrm{U} \sim 5.49 \times 10^{-5}$ ) due to slower groundwater flow, higher residence times, and dissolution of the young, chemically unstable basalt host rock.

The observed groundwater ${ }^{87} \mathrm{Sr} /{ }^{86} \mathrm{Sr}$ evolution translates to a reaction rate, based on mass balance considerations and the chemical and physical parameters of the system. Equations for calculating the reaction rate can be found in Johnson and DePaolo (1994). In the HIRZ we estimate a groundwater pore velocity of $300 \mathrm{~m} / \mathrm{year}$ in the HIRZ, ${ }^{87} \mathrm{Sr} /{ }^{86} \mathrm{Sr}$ evolution from 0.711 to 0.705 over $50 \mathrm{~km}$ distance in that zone, an effective porosity of $20 \%$, and average Sr concentrations of $300 \mathrm{ppm}$ and $0.2 \mathrm{mg} / \mathrm{l}$ in the rock and groundwater, respectively. Based on these parameters, the calculated reaction rate is $5 \%$ of the rock's inventory of Sr transferred to the fluid per million years. A similar calculation performed using the $\mathrm{U}$ isotope data gives a somewhat larger reaction rate, $15 \%$ per million years. This is consistent with expected strong partitioning of $\mathrm{U}$, during partial crystallization of the basalt lavas, into residual liquid that now forms the highly reactive glass phase.

The basalt host rocks are 1 million years old or less (Lanphere et al., 1993) and contain an unstable glass phase, so rapid reactions are expected in the aquifer. However, some of the decrease in ${ }^{87} \mathrm{Sr} /{ }^{86} \mathrm{Sr}$ within the HIRZ is caused by mixing with lower ${ }^{87} \mathrm{Sr} /{ }^{86} \mathrm{Sr}$ water from outside the HIRZ, and thus the actual reaction rate is probably lower than the above estimate. It is also likely that some of the water-rock interaction occurs somewhat below the active aquifer where temperatures, and thus reaction rates, are greater, and the reaction products are transported upward by dispersive mixing. Overall, the required reaction rate is reasonable for this system, though the details of the reactions are still being explored.

\section{Alternative Hypotheses}

Chemical heterogeneity in the host rock and influx of solute-rich hydrothermal waters from below the aquifer were considered as alternatives to the fast zone hypothesis. Essentially all of the aquifer rocks in this area are quite homogeneous tholeiitic basalts with a restricted range of ${ }^{87} \mathrm{Sr} /{ }^{86} \mathrm{Sr}$ (Leeman and Manton, 1971; Reed et al., 1997), and basalt lava flow groups have been correlated through the subsurface between the HIRZ and both the WLZ and CLZ (Anderson, 1991). 
Accordingly, chemical heterogeneity in the rock is implausible as an alternative hypothesis to explain the observed pattern. Hydrothermal input was also considered as an alternative hypothesis; there is evidence for small amounts of hydrothermal water input to the aquifer (McLing, 1994). However, to impact the large volume of water flowing through the fast-flowing upper aquifer, $\mathrm{Sr}$ and $U$ concentrations of this water would necessarily be very high. This in turn requires elevated $\mathrm{Sr}$ and $\mathrm{U}$ concentrations in the low isotope ratios zones relative to the HIRZ. Lower concentrations are observed, and thus influx of solute-laden hydrothermal water is not a viable alternative hypothesis.

Infiltration of water from the Big Lost River channel, which receives water sporadically, probably influences the ${ }^{87} \mathrm{Sr}{ }^{86} \mathrm{Sr}$ and ${ }^{234} \mathrm{U} /{ }^{238} \mathrm{U}$ patterns. During wet years, significant infiltration occurs and in the long term, a significant input to the aquifer occurs, mostly near the INEEL spreading areas (Fig. 2) and the end of the river channel in the northern area of the INEEL (Bennett, 1990). The measured ${ }^{87} \mathrm{Sr}{ }^{86} \mathrm{Sr}$ and ${ }^{2.34} \mathrm{U} /{ }^{2.38} \mathrm{U}$ ratios of a water sample from the river are 0.71056 and $123.8 \mathrm{ppm}$, respectively. Given these values, the Big Lost River infiltration alone cannot explain the observed ${ }^{87} \mathrm{Sr} /{ }^{86} \mathrm{Sr}$ and ${ }^{234} \mathrm{U} /{ }^{238} \mathrm{U}$ patterns, but likely contributes to them. This issue is discussed in more detail by Roback et al (Submitted).

Similarly, water input from the local groundwater system draining the fringe of the Lost River Range, directly north of the WLZ, also probably contributes to the observed pattern. This water could have relatively low ${ }^{87} \mathrm{Sr} /{ }^{86} \mathrm{Sr}$ values inherited from the carbonate rocks that dominate the watershed. However, this watershed is much smaller than that of the Little Lost River and the input to the Snake River Plain Aquifer is therefore much smaller. A local low isotope ratio zone could result from this input, but the flux of water is not sufficient to produce the entire WLZ and divert the dominant Little Lost River valley input eastward.

Based on the above evidence, we conclude that the ${ }^{87} \mathrm{Sr} /{ }^{36} \mathrm{Sr}$ and ${ }^{2.34} \mathrm{U} /{ }^{2.38} \mathrm{U}$ patterns reflect the presence of fast and slow groundwater flow zones on a regional scale. The apparent direction of flow in the HIRZ is nearly due south; this is consistent with a local flow direction revealed by a contaminant plume near the center of the HIRZ (Barraclough et al., 1982). Flow is not parallel to 
the regional hydraulic gradient as given in Barraclough et al. (1982). This implies hydraulic anisotropy, which is consistent with the dominant NW-SE trend of the lava flows and recent research on anisotropy (Welhan and Reed, 1997). The velocity in the HIRZ is apparently more than a factor of 5 greater than that in the WLZ, as the distance over which a given change in ${ }^{87} \mathrm{Sr} /{ }^{86} \mathrm{Sr}$ in the HIRZ occurs is more than 5 times greater than that in the WLZ. Numerical modeling that takes into account dispersive mixing and other details is in progress to provide a more rigorous estimate of this velocity contrast.

\section{Radiogenic Isotopes Versus Concentration Data}

Elemental concentration data (Fig. 2) exhibit spatial patterns with some similarities to the ${ }^{87} \mathrm{Sr} /{ }^{86} \mathrm{Sr}$ and ${ }^{2.34} \mathrm{U} /{ }^{2.38} \mathrm{U}$ data, but the patterns are not as consistent as the isotope patterns. A tongue of high $\mathrm{Mg}$ concentration and low $\mathrm{Na}$ and Si concentrations weakly resembles the HIRZ. Also, an area of high $\mathrm{Na}$ and $\mathrm{Si}$ concentrations corresponding to the WLZ apparently reflects net release of $\mathrm{Na}$ and $\mathrm{SiO}_{2}$ by the rock as a result of water-rock interaction. However, the lack of inter-element coherence of the patterns in the concentration data suggest that they are less reliable than the isotope ratios as indicators of residence times and flow paths. Examination of other concentration data (e.g., $\mathrm{Ca}, \mathrm{Ba}$, and $\mathrm{Sr}$ ) further supports this assessment.

The effects of water-rock interaction on radiogenic isotope ratios are fundamentally different from the effects on elemental concentrations, and as a result the isotope ratios are superior indicators of relative groundwater residence time. An elemental concentration changes according to the difference between solute gains due to dissolution, ion exchange, and desorption and solute losses due to precipitation, ion exchange, and adsorption. A concentration can thus be expected to evolve in a complex way, according to the difference between solute losses and solute gains. For example, dissolution of basalt is likely accompanied by precipitation of clay minerals, because even

small amounts of aluminum in solution $(0.1$ to $1 \mu \mathrm{g} / \mathrm{l})$ will result in supersaturation (Drever, 1988). The compositions of the precipitated clay minerals are sensitive to spatial variations in $\mathrm{pH}$, 
temperature, and other variables, and thus the net effect of water-rock interaction is difficult to predict.

In contrast, the ${ }^{87} \mathrm{Sr} /{ }^{86} \mathrm{Sr}$ or ${ }^{234} \mathrm{U} /{ }^{238} \mathrm{U}$ ratio of the water is unaffected by solute losses due to precipitation, ion exchange, or adsorption, because the $\mathrm{Sr}$ or $\mathrm{U}$ transferred to the solid phases is isotopically identical to that of the parent water (Johnson and DePaolo, 1994). Transfer of Sr or U from rock to groundwater forces the ${ }^{87} \mathrm{Sr} /{ }^{86} \mathrm{Sr}$ or ${ }^{234} \mathrm{U} /{ }^{2.38} \mathrm{U}$ toward the isotope ratio of the $\mathrm{Sr}$ or $\mathrm{U}$ transferred from the rock. In this way, isotope ratios provide a record of water/rock interaction that is more reliable than that obtained from solute concentration data. In this study, both isotope ratios evolve toward predictable isotopic equilibrium values $\left(0.70700 \pm 0.0003\right.$ for ${ }^{87} \mathrm{Sr} /{ }^{86} \mathrm{Sr} ; 5.49 \times 10^{-5}$ for ${ }^{2.34} \mathrm{U} /{ }^{2.38} \mathrm{U}$ ) in response to water-rock interaction, whereas the solute concentration evolution is difficult to predict. Thus, the consistency and robustness of the isotope ratio patterns illustrate the strengths of isotope ratios as groundwater tracers. This is not to say that isotope ratios should be studied to the exclusion of other data, but that they should be added more commonly to the list of chemical measurements made in groundwater studies.

Isotope ratios, and hydrochemical patterns in general, may also be better indicators of fast flow zones than hydraulic head data in many cases. Whereas fast flow paths are expected to give tongue-like ${ }^{87} \mathrm{Sr} /{ }^{86} \mathrm{Sr}$ patterns in reactive systems (Johnson and DePaolo, 1994), the resulting hydraulic head data patterns are more complicated and less easily interpreted. Fig. 4, a schematic hydraulic head map for a fast flow zone, illustrates the pattern expected for a narrow high conductivity zone. The existence of the fast path results in distortion of the regional head contours near the beginning and end of the fast path, but not in its core. In a natural system, this pattern could be masked by other hydrologic features outside the fast flow zone. Ultimately, geochemical and hydraulic head data are best combined in the search for fast paths; work is currently underway to interpret both data sets from the Snake River Plain aquifer using a single flow and reactive transport model . 


\section{CONCLUSIONS}

The strong patterns observed in ${ }^{87} \mathrm{Sr} /{ }^{86} \mathrm{Sr}$ and ${ }^{234} \mathrm{U} /{ }^{238} \mathrm{U}$ in the Snake River Plain aquifer reflect the presence of fast and slow flow zones, and arise from reaction of groundwater with the young, glassy basalt host rocks. The high isotope ratio zone trending southward from the Little Lost River Valley and passing through the southern boundary of the INEEL is a high groundwater velocity zone flanked by slower zones. The isotope ratios are more useful in imaging this flow pattern than concentration data, because of the simpler systematics of isotope ratios in reactive water-rock systems.

Our success in revealing flow patterns with ${ }^{87} \mathrm{Sr} /{ }^{86} \mathrm{Sr}$ and ${ }^{234} \mathrm{U} /{ }^{238} \mathrm{U}$ in the Snake River Plain aquifer should translate to other groundwater settings, such as Karstic systems. The fundamental properties of these isotope ratios make them "well behaved" tracers in systems where chemical interaction between water and rock is important. Improvements in instrumentation and sample preparation have made isotope ratio analyses less expensive and more accessible. Given the high costs of well drilling and sampling at many sites, the incremental cost of obtaining isotope data is

relatively small. Isotope ratios of $\mathrm{Sr}, \mathrm{U}, \mathrm{Pb}$ and $\mathrm{Nd}$, which until recently were viewed by most hydrologists as exotic, expensive measurements, have an important role in the array of techniques used to reveal fast flow paths in groundwater systems.

\section{REFERENCES}

Ackerman, D.J., 1995, Analysis of steady-state flow and advective transport in the eastern Snake River plain aquifer system, Idaho, Water-Resources Investigations - U. S. Geological Survey: [Reston, VA], United States, U. S. Geological Survey, p. 25.

Anderson, S.R., 1991, Stratigraphy of the unsaturated zone and uppermost part of the Snake River Plain Aquifer near the Idaho Chemical Processing Plant and Test reactor Area, Idaho National Engineering Laboratory, Idaho, U.S. Geological Survey, p. 71. 
Barraclough, J.T., Lewis, B.D., and Jensen, R.G., 1982, Hydrologic conditions at the Idaho National Engineering Laboratory; Idaho; emphasis 1974-1978, U. S. Geological Survey WaterSupply Paper: Reston, VA, United States, U. S. Geological Survey, p. 52.

Beasley, T.M., Cecil, L.D., Sharma, P., Kubik, P.W., Mann, L.J., Gove, H.E., and Fehn, U., 1993, Chlorine-36 in the Snake River Plain Aquifer at the Idaho National Engineering Laboratory; origin and implications: Ground Water, v. 31, p. 302-310.

Bennett, C.M., 1990, Streamflow losses and ground-water level changes along the Big Lost River at the Idaho National Engineering Laboratory, Idaho, Water Resources Investigations Report 90-4067: Reston, VA, United States, U. S. Geological Survey, p. 49.

Blackwell, D.D., Kelley, S., and Steele, J.L., 1992, Heat flow modeling of the Snake River Plain, Idaho. EG\&G Idaho, p. 109pp.

Blum, J.D., Erel, Y., and Brown, K., 1993, ${ }^{87} \mathrm{Sr} /{ }^{86} \mathrm{Sr}$ ratios of Sierra Nevada stream waters; implications for relative mineral weathering rates: Geochimica et Cosmochimica Acta, v. 57, p. 5019-5025.

Bullen, T.D., White, A.F., Blum, A.E., Harden, J.W., and Schulz, M.S., 1997, Chemical weathering of a soil chronosequence on granitoid alluvium; II, Mineralogic and isotopic constraints on the behavior of strontium: Geochimica et Cosmochimica Acta, v. 61, p. 291306.

Busenberg, E., Weeks, E.P., Plummer, L.N., and Bartholomay, R.C., 1993, Age dating groundwater by the use of chlorofluorocarbons $\left(\mathrm{CCl}_{3} \mathrm{~F}\right.$ and $\left.\mathrm{CCl}_{2} \mathrm{~F}_{2}\right)$ and distribution of chlorofluorocarbons in the unsaturated zone, Snake River Plain Aquifer, Idaho National Engineering Laboratory, Idaho., U. S. Geological Survey.

Clark, I.D., and Fritz, P., 1997, Environmental Isotopes in Hydrogeology: New York, Lewis, $328 \mathrm{p}$.

Drever, J.I., 1988, The geochemistry of natural waters: Englewood Cliffs, NJ, United States, Prentice-Hall, $437 \mathrm{p}$. 
Garabedian, S.P., 1992, Hydrology and digital simulation of the regional aquifer system, eastern Snake River plain, Idaho, U. S. Geological Survey Professional Paper: Reston, VA, United States, U. S. Geological Survey, p. F1-F102.

Johnson, T.M., and DePaolo, D.J., 1994, Interpretation of isotopic data in groundwater-rock systems; model development and application to Sr isotope data from Yucca Mountain: Water Resources Research, v. 30, p. 1571-1587.

Johnson, T.M., and DePaolo, D.J., 1997, Rapid exchange effects on isotope ratios in groundwater systems; 2, Flow investigation using Sr isotope ratios: Water Resources Research, v. 33 , p. $197-209$.

Kuntz, M.A., Covington, H.R., and Schorr, L.J., 1992, An overview of basaltic volcanism of the eastern Snake River plain, Idaho, in Link, P.K., Kuntz, M.A., and Platt, L.B., eds., Regional geology of eastern Idaho and western Wyoming., Volume 179: Memoir - Geological Society of America: Boulder, CO, United States, Geological Society of America (GSA), p. 227-267.

Lanphere, M.A., Champion, D.E., and Kuntz, M.A., 1993, Petrography, age, and paleomagnetism of basalt lava flows in coreholes Well 80, NRF 89-04, NRF 89-05, amd ICPP-123, Idaho National Engineering Laboratory: Menlo Park, CA, U.S. Geological Survey, p. 40pp.

Leeman, W.P., and Manton, W.I., 1971, Strontium isotopic composition of basaltic lavas from the Snake River plain, southern Idaho: Earth and Planetary Science Letters, v. 11, p. 420-434.

Mann, L.J., and Cecil, L.D., 1986, Hydraulic properties of rock units and chemical quality of water for INEL-1- A 10,365-foot deep test hole drilled at the Idaho National Engineering Laboratory, Idaho, U.S. Geological Survey, p. 23.

Mann, L.J., and Cecil, L.D., 1990, Tritium in groundwater at the Idaho National Engineering Laboratory, Idaho, U.S. Geological Survey, p. 71.

McLing, T.M., 1994, The pre-anthropogenic groundwater evolution at the Idaho National Engineering Laboratory, Idaho [M. S. Thesis thesis], Idaho State Univ. 
Musgrove, M., and Banner, J.L., 1993, Regional ground-water mixing and the origin of saline fluids; Midcontinent, United States: Science, v. 259, p. 1877-1882.

Naftz, D.L., Peterman, Z.E., and Spangler, L.E., 1997, Using delta ${ }^{87} \mathrm{Sr}$ values to identify sources of salinity to a freshwater aquifer, Greater Aneth oil field, Utah, USA: Chemical Geology, v. 141, p. 195-209.

Osmond, J.K., and Cowart, J.B., 1992, Ground water, in Ivanovich, M., and Harmon, R.S., eds., Uranium-series disequilibrium; applications to Earth, marine, and environmental sciences.: Oxford, United Kingdom, Clarendon Press, p. 290-333.

Reed, M.F., Bartholomay, R.C., and Hughes, S.S., 1997, Geochemistry and stratigraphic correlation of basalt lavas beneath the Idaho Chemical Processing Plant, Idaho National Engineering Laboratory: Environmental Geology, v. 30, p. 108-118.

Roback, R.C., Murrell, M., Nunn, A., Johnson, T., McCling, T., Luo, S., and Ku, R., Submitted, Groundwater mixing, flow-paths and water/ rock interaction at INEEL; evidence from uranium isotopes: GSA Bulletin.

Tsang, C.F., and Neretnieks, I., 1998, Flow channeling in heterogeneous fractured rocks: Reviews of Geophysics, v. 36, p. 275-298.

Welhan, J.A., and Reed, M.F., 1997, Geostatistical analysis of regional hydraulic conductivity variations in the Snake River Plain Aquifer, eastern Idaho: Geological Society of America Bulletin, v. 109, p. 855-868.

\section{FIGURE CAPTIONS}

Fig. 1. The Snake River Plain Aquifer and the watersheds that recharge it. The regional groundwater flow direction is NE to SW.

Fig. 2. Contour plots of (A) ${ }^{87} \mathrm{Sr} /{ }^{86} \mathrm{Sr}$, (B) Li concentration, (C) $\mathrm{Na}$ concentration, (D) $\mathrm{Mg}$ concentration, and (E) Si concentration in groundwater. Sample locations are given by black circles, and the INEEL boundary is given by the dashed line. The channel of the Big Lost River is 
shown in (A). Spreading areas to which water is diverted during high runoff periods are outlined just south of the southermost point on the river channel. Contours were derived initially by Kriging, and were modified by hand to reflect the existence of aquifer boundaries and regional flow directions.

Fig. 3. Contour plot of ${ }^{234} \mathrm{U} /{ }^{2.38} \mathrm{U}$ data obtained by Roback et al., (submitted) from many of the same wells as the present study. $\mathrm{U}$ isotope systematics are different from those of $\mathrm{Sr}$, but the resulting patterns in the groundwater are similar.

Fig. 4. Schematic representation of hydraulic head disturbances created by the existence of a fast flow zone. 


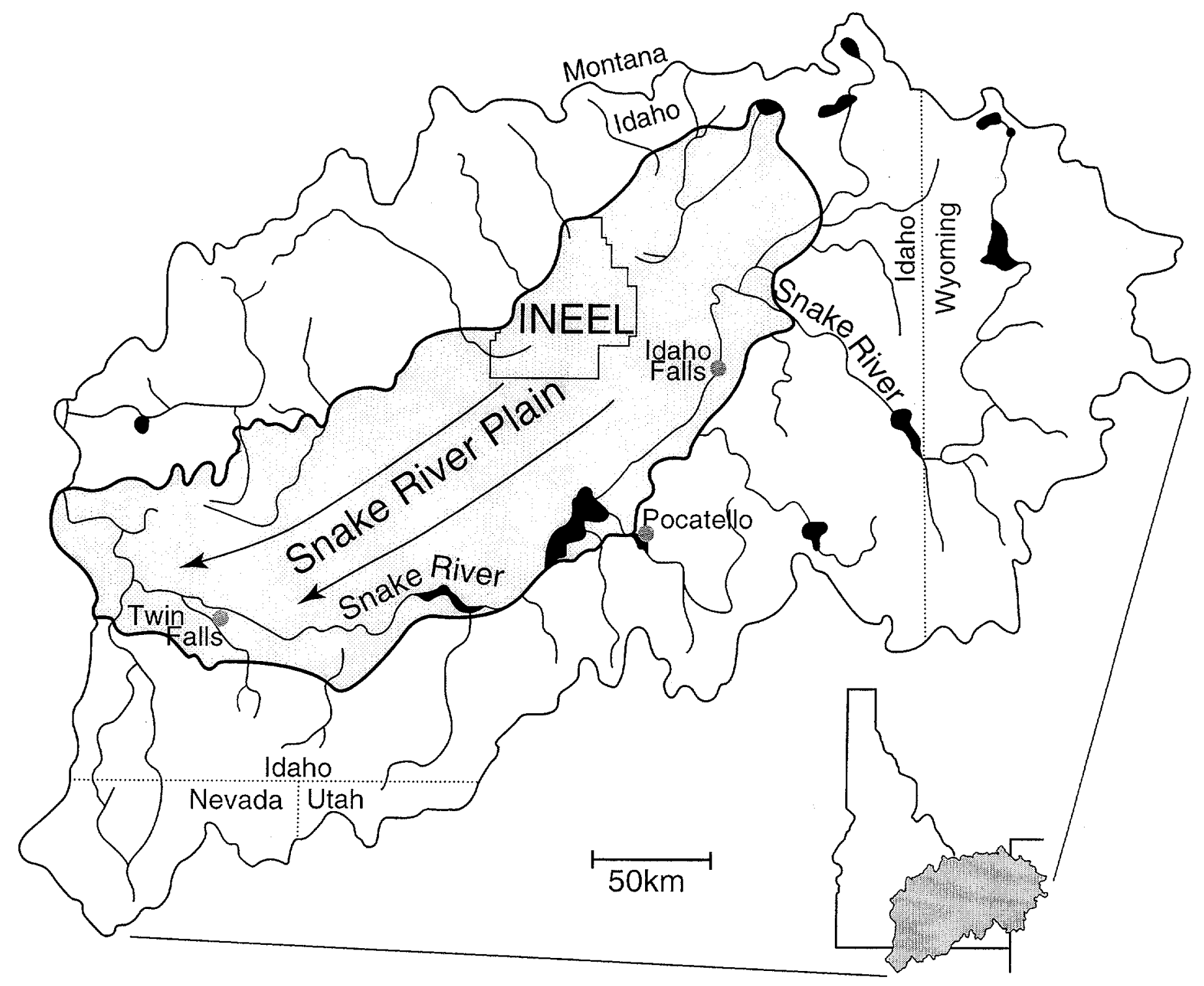

Johnson et al., figure 1 


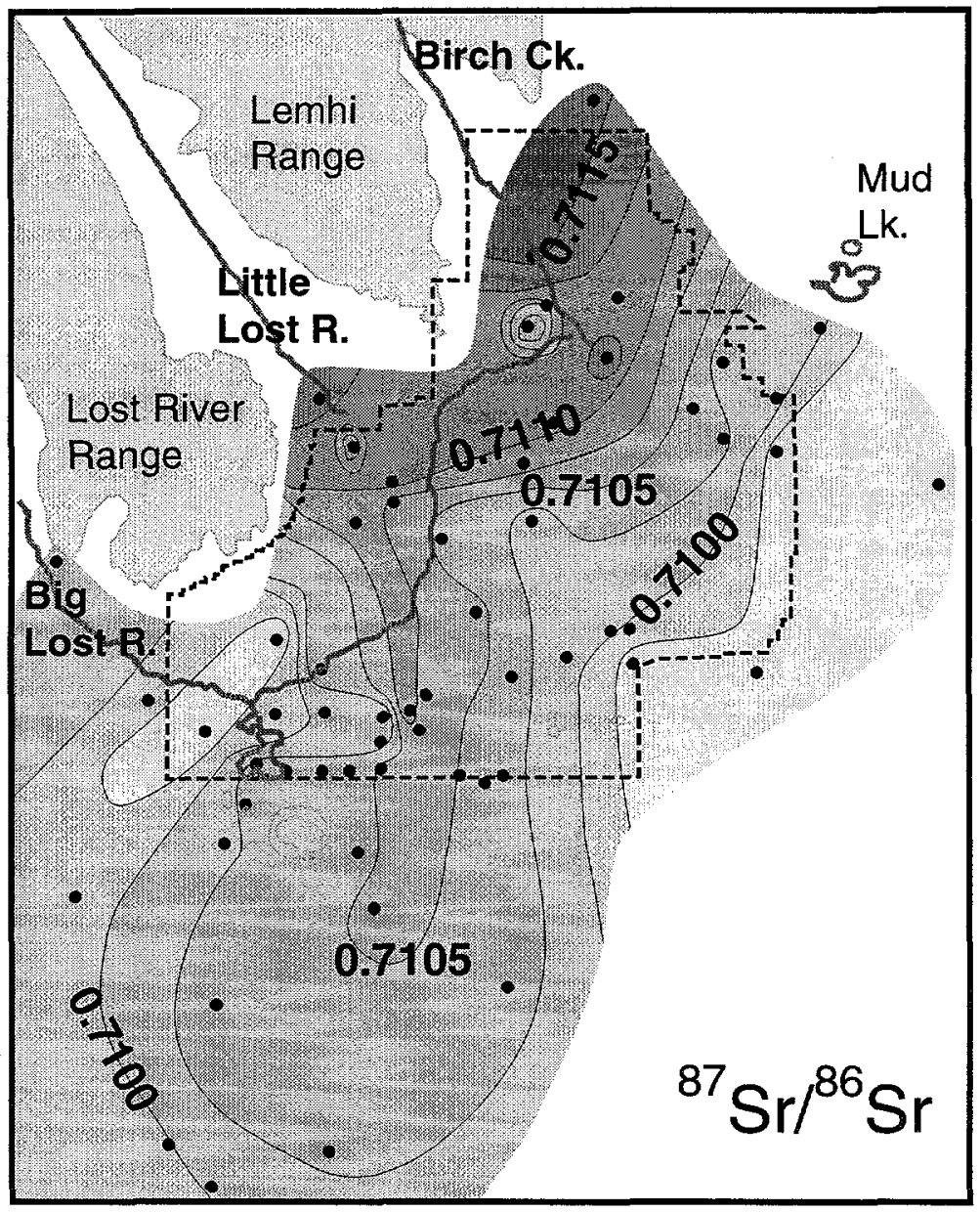

Fig. $2 a$ 


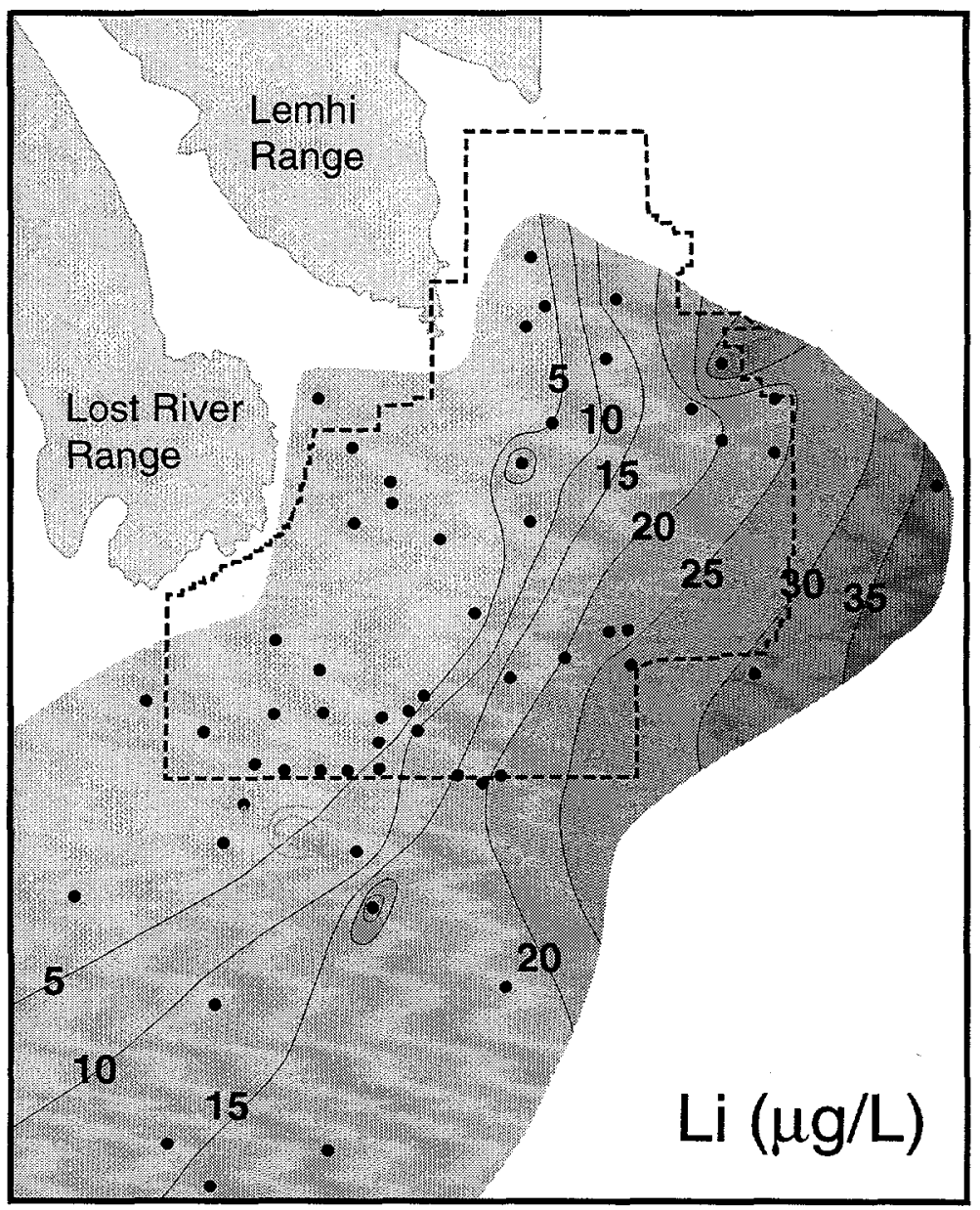

Fig. $2 b$ 


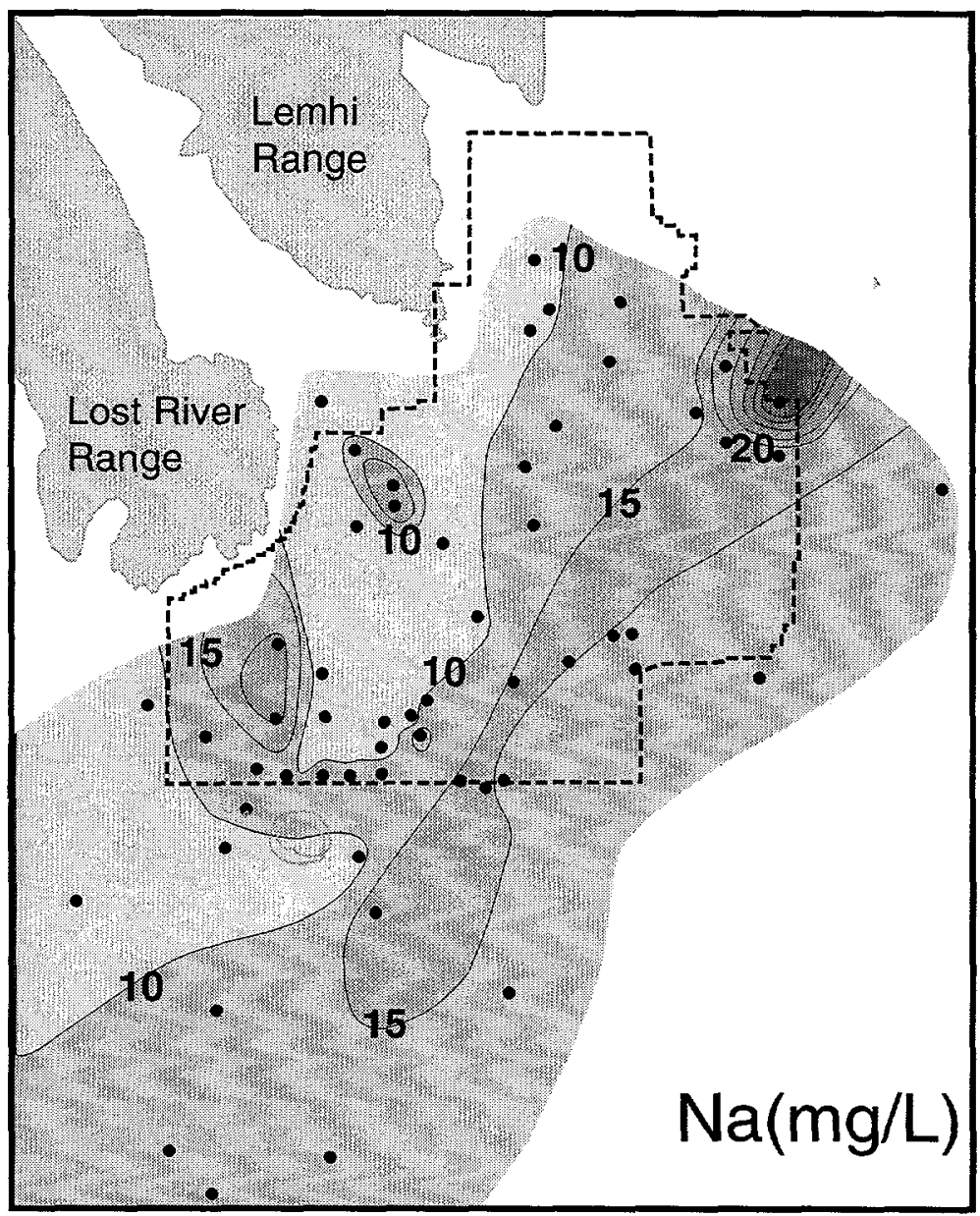

$2 c$ 


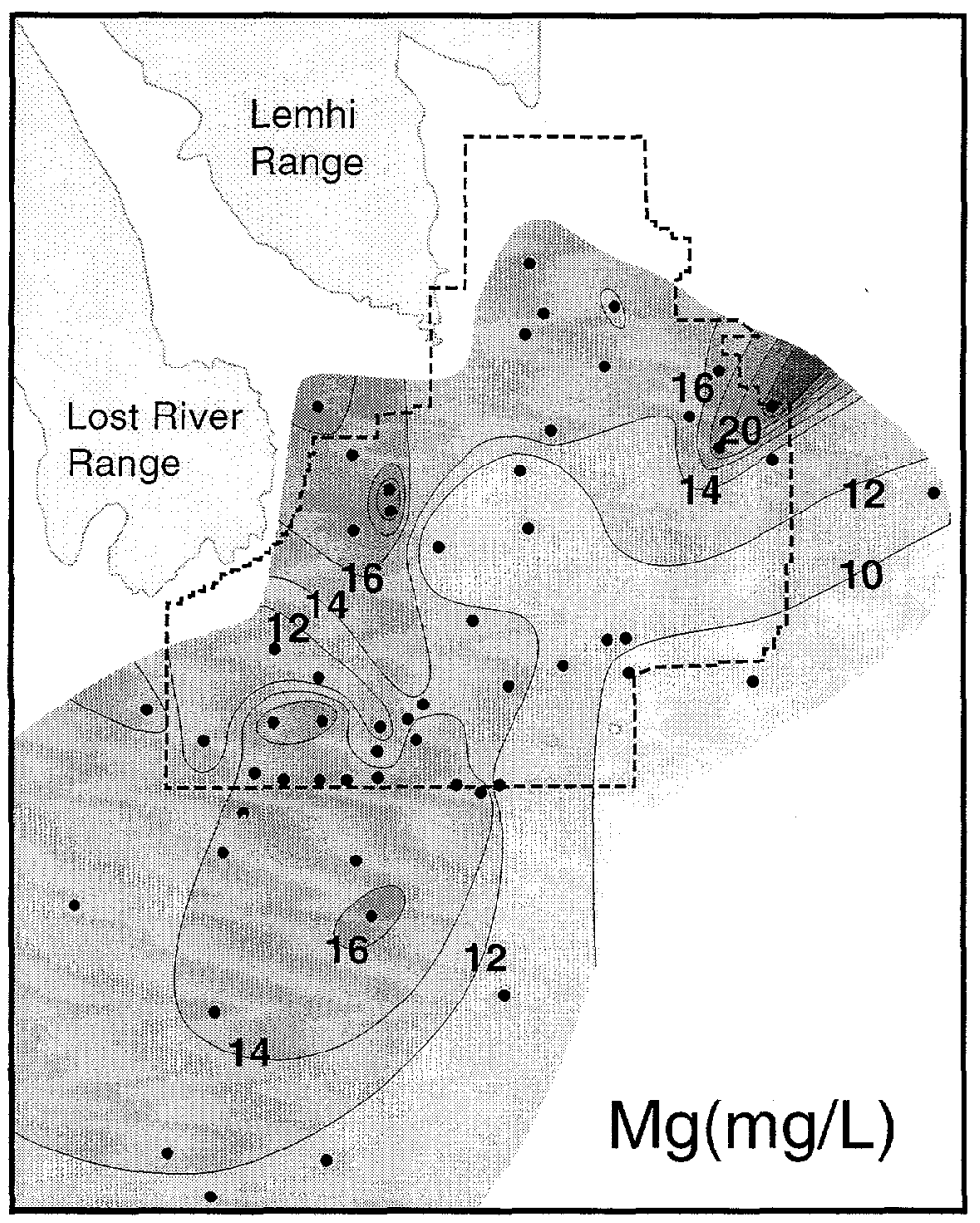




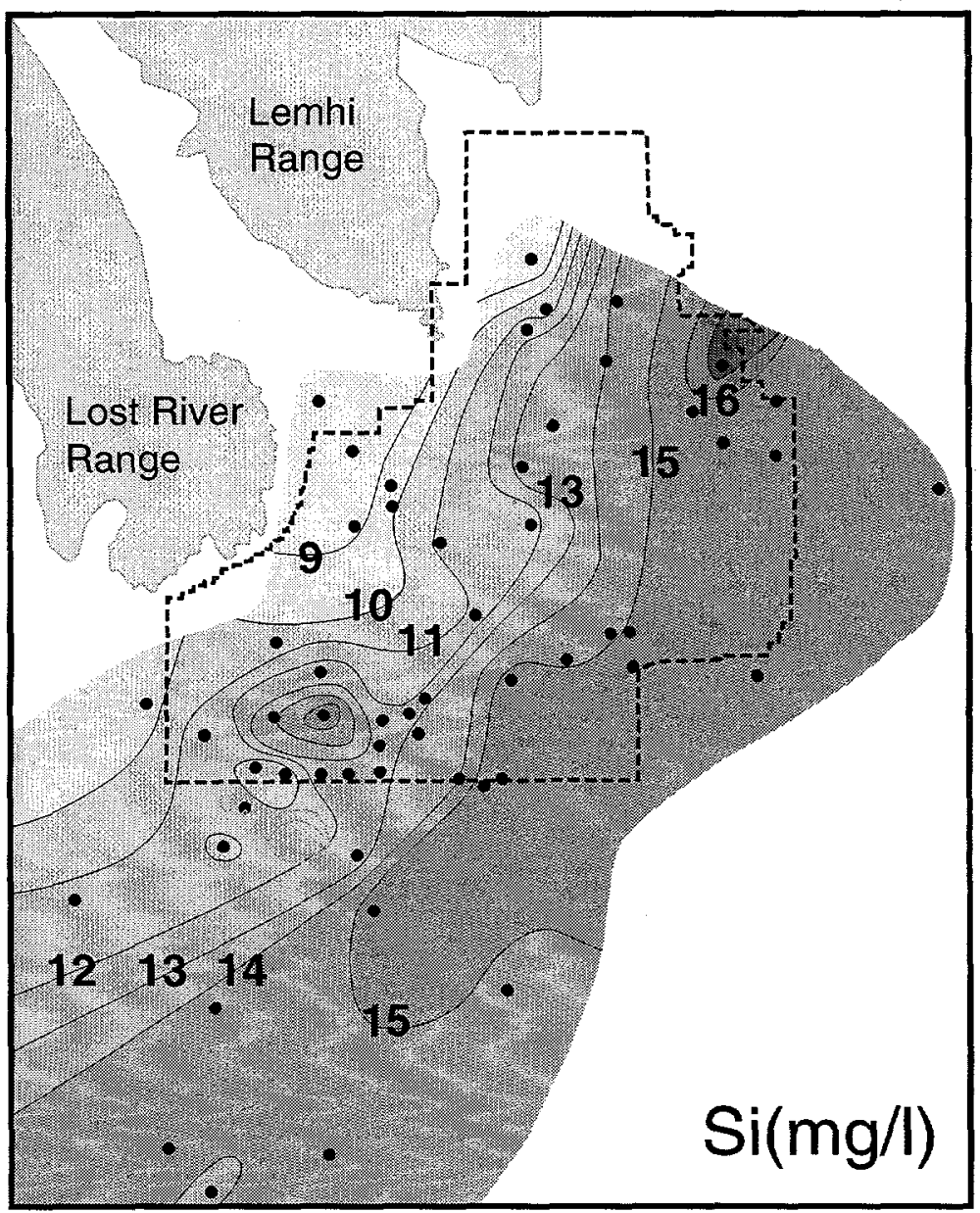

$2 e$ 


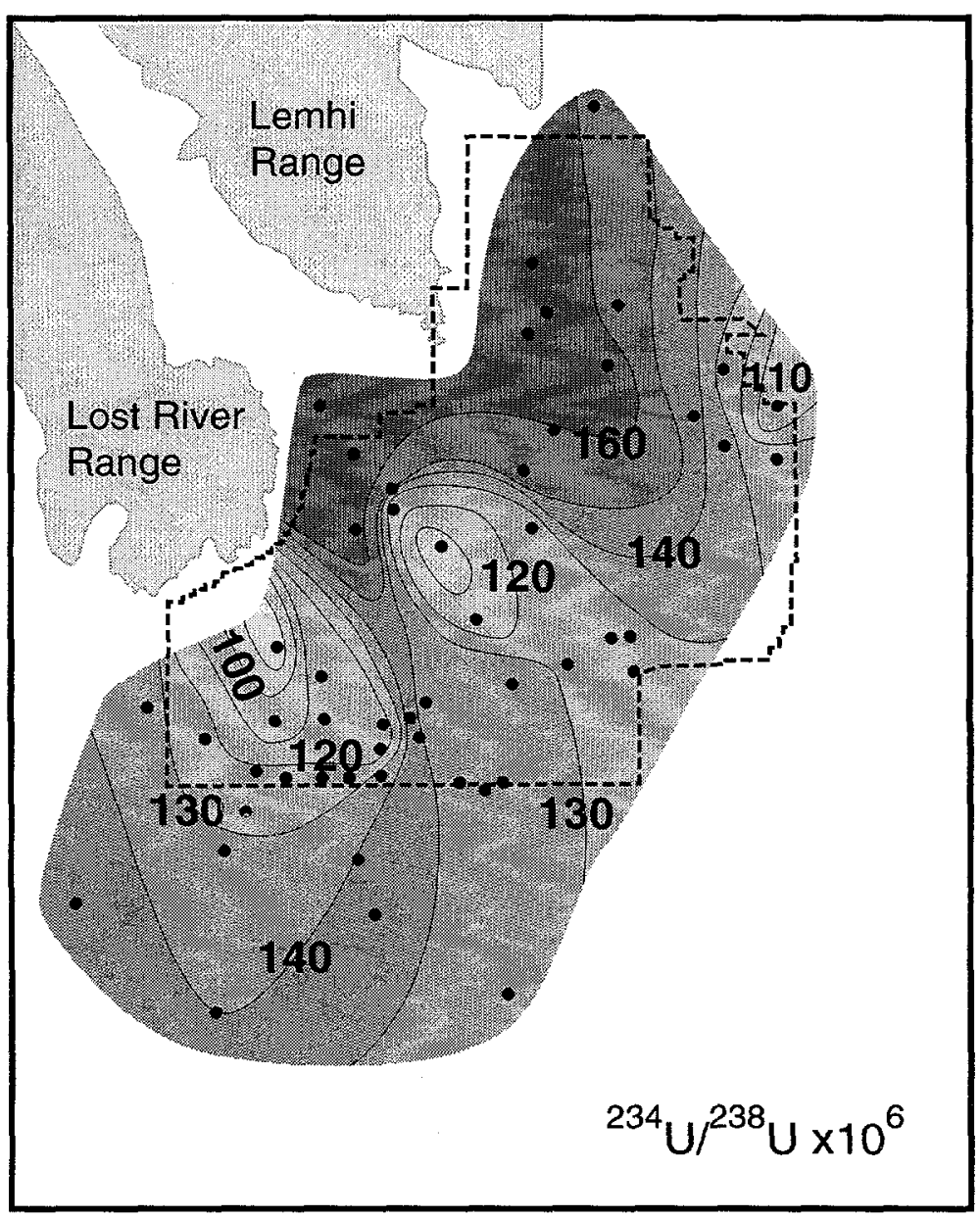

Fig. 3 


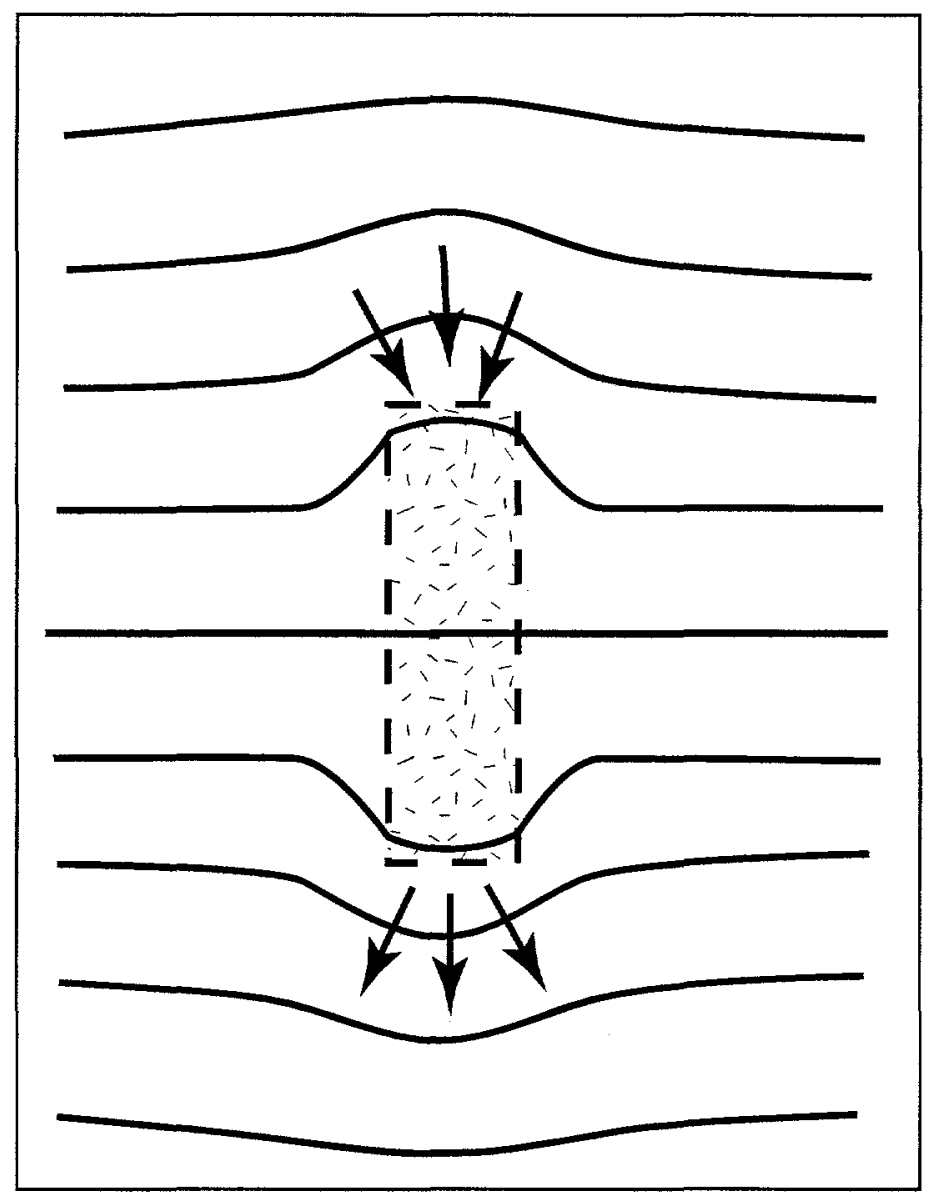

Fig. 4 